\title{
MILK COMPOSITIONAL
}

\section{QUALITY AND ITS}

IMPORTANCE IN FUTURE

\section{MARKETS}

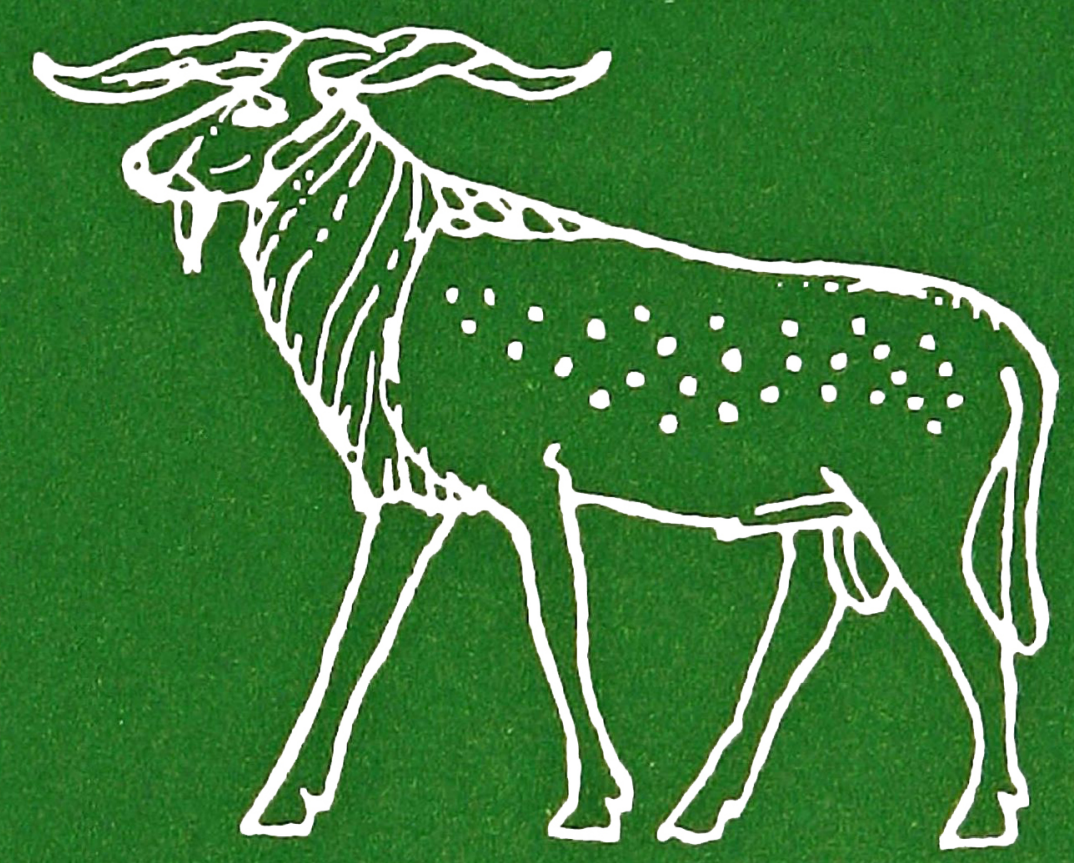

AN OCCASIONAL PUBLICATION

OF THE

BRITISH SOCIETY OF ANIMAL, PROIUCTION 
The British Society of Animal Production's Occasional Publication Series contains the full papers presented at certain symposia organized by the Society. A full list of titles is given at the back of this Publication. Copies may be obtained from the British Society of Animal Production, c/o Farms Division Office, Bush Estate, Penicuik, Midlothian, EH26 0PH, Scotland. 


\title{
MILK COMPOSITIONAL QUALITY AND ITS \\ IMPORTANCE IN FUTURE MARKETS
}

Proceedings of a symposium organized by THE BRITISH SOCIETY OF ANIMAL PRODUCTION and held in Harrogate in February 1984

\section{BSAP OCCASIONAL PUBLICATION Number 9}

edited by M. E. CASTLE and R. G. GUNN

\author{
BSAP
}

EDINBURGH

1984 
ISBN 0906562090

(C) 1984 THE BRITISH SOCIETY OF ANIMAL PRODUCTION

Printed in Great Britain by D. \& J. Croal Ltd., Haddington. 


\section{ACKNOWLEDGEMENTS}

The Society thanks the following for organizing the symposium:

M. E. Warren

Mrs J. M. Newton

J. R. Mulholland

Dr J. D. Sutton

and Dr L. K. O’Connor

G. Alderman

Prof. J. H. D. Prescott for chairing the sessions. 


\section{LIST OF DELEGATES}

Dr D. M. Allen, Hon. President BSAP,

MLC, P.O. Box 44, Queensway House, Bletchley, Milton Keynes, MK2 2EF.

Alderman, G.

Amies, S. J.

Asby, Dr C. B.

Bachoc, P.

Baker, S.

Banks, Dr W.

Banton, C. L.

Barber, W. P.

Beer, J. H.

Bell, Miss E. M.

Booth, Miss A. M.

Booth, J. M.

Brigstocke, T. D. A.

Brown, F. D.

Brumby, Dr P. E.

Castle, Dr M. E.

Chambers, $\mathrm{S}$.

Chandler, N. J.

Chapman, J.

Collis, K. A.

Connolly, L. P.

Crabtree, Dr R. M.

Craven, Dr J.

Crehan, M. P.

Crofts, $\mathrm{T}$.

Crooks, R. H.

Crossley, A.

Cuthbert, N. H.

Devine, D. F. Dodd, Dr F. H.

Duff, W. G.
Great Westminster House, Horseferry Road, London, SW1. Milk Marketing Board, Thames Ditton, Surrey.

Shuttleworth College, Old Warden Park, Biggleswade, Bedfordshire.

Elanco, Lilly House, Hanover Square, London, W1R 0PA.

Colborn-Dawes Nutrition Ltd., Heanor Gate, Heanor, Derbyshire.

Hannah Research Institute, Ayr, KA6 5HL.

BP Nutrition (UK) Ltd., Wincham, Northwich, Cheshire, CW9 6DF.

ADAS, Feed Evaluation Unit, Alcester Road, Stratford on Avon, Warwicks, CV37 9RQ.

W. \& J. Pye Ltd., Fleet Square, Lancaster, Lancs.

APAD, East of Scotland College of Agriculture, Bush Estate, Penicuik, Midlothian, EH260QE.

Page Feeds, Mill Lane, Tadcaster, North Yorkshire.

MMB, Veterinary Laboratory, Cleeve House, Lower Wick, Worcester, WR2 4NS.

BOCM Silcock Ltd., Mill Lane, Alton, Hants, GU34 2QS

Farmers Guardian, 11 Lennox Drive, Wakefield, WF2 8LL.

Dalgety Spillers Feed Ltd., The Promenade, Clifton, Bristol, BS8 $3 \mathrm{NJ}$.

Tobergill, Low Coylton, Ayrshire, KA6 6HG.

Express Creameries Ltd., Priestdykes, Lockerbie, Dumfries.

36 Hamilton Square, Birkenhead, Merseyside, L41 5BP.

Milk Marketing Board, Thames Ditton, Surrey.

Alfa Laval Co. Ltd., Oakfields, Cwmbran, Gwent.

5 Amber Gardens, Andover, Hants.

ADAS, Staplake Mount, Starcross, Exeter, Devon, EX6 8PE.

Farm Management Services, MMB, 3 Grove Road, Wrexham,

Clwyd.

Nutec Ltd., Eastern Avenue, Lichfield, Staffs.

British Farmer, Surrey House, Throwley Way, Sutton, Surrey, SM1 4QQ.

Hampshire College of Agriculture, Sparsholt, Winchester, Hants. Trawsgoed EHF, Trawsgoed, Nr. Aberystwyth, Dyfed, SY23 4HT.

BOCM Silcock Ltd., Basing View, Basingstoke, Hants, RG21 2EQ.

34 Northampton Lane, Dunchurch, Rugby, Warks, CV22 6PS. NIRD, Shinfield, Reading, RG2 9AT.

Scottish MMB, Underwood Road, Paisley, PA3 1TJ. 
Easterbrooke, J. P.

Edge, D. W.

Entwistle, J.

Evans, Dr P. J.

Fallows, Dr S.

Farmer, Miss P. E.

Ferns, H. R.

Forbes, A. M.

Forster, N. C.

Foster, S.

Francis, G. H.

Francis, $\mathrm{T}$.

Freeman, Dr C. P. Frood, Dr I. J. M.

Garven, R.

Gordon, Dr F.

Gough, Mrs R. M.

Gregory, N. C.

Gross, G.

Halley, R. J.

Hamilton, G.

Hannah, J. D.

Harland, Dr J. I.

Hayes, Dr M. J.

Holmes, Miss N.

Hope, $\mathrm{H}$.

Hughes, G. D.

Ingham, J.

Johnson, C. L.

Jones, Dr E. W.
John Easterbrooke and Partners Ltd., Gold Hill House, Shaftesbury, Dorset.

Pauls Agriculture Ltd., Road One-Industrial Estate, Winsford, Cheshire.

Dalgety Spillers Feed Ltd., The Promenade, Clifton, Bristol, BS8 3NJ.

Unilever Research Ltd., Colworth House, Sharnbrook, Beds.

School of Science and Society, University of Bradford, Bradford, BD7 1DP.

MAFF, Burghill Road, Westbury-on-Trym, Bristol.

West of Scotland Agricultural College, Auchincruive, Ayr.

Farm Feed Formulators, Darlington Road, Northallerton, North Yorkshire.

BOCM Silcock Ltd., Basing View, Basingstoke, Hants, RG21 2EQ.

Rumenco Ltd., Stretton House, Derby Road, Burton on Trent, DE13 0DW.

ADAS, MAFF, Block C, Government Buildings, Brooklands Avenue, Cambridge.

Yorkshire Post, Wellington Street, Leeds.

Unilever Research Ltd., Colworth House, Sharnbrook, Beds.

Old Hall, Corringham, Essex, SS17 7RN.

51 Rodney Drive, Girvan, Ayrshire.

Agricultural Research Institute of Northern Ireland, Hillsborough, Co. Down.

John Easterbrooke and Partners Ltd., Gold Hill House, Shaftesbury, Dorset.

West Midland Farmers' Assn. Ltd., Llanthony Mills, Merchants Road, Gloucester.

Bayles and Wylie Ltd., Forge Mills, Bestwood, Nottingham.

Seale Hayne College, Newton Abbot, Devon.

c/o E. B. Bradshaw and Sons, Bell Mills, Driffield, N. Humberside, YO25 7XL.

Scottish MMB, Underwood Road, Paisley, PA3 1TJ.

British Sugar PLC., P.O. Box 26, Oundle Road, Peterborough, PE2 9QU.

'Chota Koti', Oakley Road, Battledown, Cheltenham, GL52 6PA.

Big Farm Weekly, 93-99 Goswell Road, London, EC1V 7QA.

Farmers Weekly, Surrey House, 1 Throwley Way, Sutton, Surrey.

1 Peryn Road, Tavistock, Devon.

Inghams Stockfeeders Ltd., Whitebirk Industrial Estate, Blackburn, BB1 5SL.

Dept. of Animal Physiology and Nutrition, University of Leeds, Leeds, LS2.9JT.

Welsh Agricultural College, Llanbadarn Fawr, Aberystwyth, Dyfed. 
Jones, W. T.

Kabuga, J. D.

Kelly, P.

King, Prof. J. W. B.

Kosinski, Dr E. D.

Lennon, J. S.

Lightfoot, S.

Lindeman, M. A.

Lonsdale, Dr C. R.

Lyon-Smith, Mrs P. C. Main, J.

Mansbridge, Miss R. J.

Marsden, S.

Matthewman, R. W.

Maudlin, Miss D.

Mayne, Dr S.

Mead, S.

Metcalfe, R.

Miller, Miss R.

Morgan, H. E. G.

Morris, Miss J. V.

Muir, Dr D. D.

Mulholland, J. R.

Murray, A. G.

Nagle, $\mathrm{J}$.

Neilson, D. R.

Newton, Mrs J. M.

O'Connor, Dr L. K.

Overend, Dr M. A.

Owers, Dr M. J.

Pearson, Dr J. T.
J. Bibby Agric. Ltd., Adderbury, Banbury, Oxon, OX17 3HL.

Edinburgh School of Agriculture, West Mains Road, Edinburgh, EH93JG.

ADAS, Nutrition Chemistry, Olantigh Road, Wye, Ashford, Kent.

AFRC, Animal Breeding Liaison Group, School of Agriculture, West Mains Road, Edinburgh, EH9 3JG.

Dairy Crest, R \& D Division, Crudgington, Telford, Shropshire. Dalgety Spillers Ltd., Aston Nantwich, Cheshire, CW5 8DH.

Colborn-Dawes Nutrition Ltd., Heanor Gate, Heanor,

Derbyshire.

BOCM Silcock Ltd., Basing View, Basingstoke, Hants, RG21 2EQ.

Kenneth Wilson (Grain) Ltd, Morwick Hall, York Road, Leeds, LS15 4NB.

26 Church Street, Broseley, Shropshire, TN2 5BX.

Farmore Farmers Ltd., Farmore Mills, Craven Arms, Shropshire, SY7 9QG.

ADAS, Block C, Government Buildings, Brooklands Road, Cambridge.

Dalgety Spillers Feed Ltd., Avonmouth, Bristol, BS11 9DR.

Centre for Tropical Veterinary Medicine, Easter Bush, Roslin, Midlothian, EH25 9RG.

Pauls Agriculture Ltd., Walton Summit, Bamber Bridge, Preston, Lancs.

Grassland Research Institute, North Wyke, Okehampton. Devon.

6 Eden Close, Great Salkeld, Penrith, Cumbria.

Pauls Agriculture Ltd., Walton Summit, Bamber Bridge, Preston,

Lancs.

Milk Marketing Board, Thames Ditton, Surrey.

WOAD, Trawsgoed, Aberystwyth, SY23 4HT.

Lackham College of Agriculture, Lacock, Chippenham, Wilts. SN15 2NY.

Hannah Research Institute, Ayr, KA6 5HL.

MAFF, Great Westminster House, Horseferry Road, London, SW1 2AE.

West Cumberland Farmers Ltd., Geltsdale, Wetheral, Carlisle. Ballyclough Co-operative, Cork.

APAD, East of Scotland College of Agriculture, Bush Estate. Penicuik, Midlothian, EH260QE.

BSAP, c/o Milk Marketing Board, Thames Ditton, Surrey.

Milk Marketing Board, Thames Ditton, Surrey.

B. Dugdale and Son Ltd., Bellman Mill, Salthill, Clitheroe, Lancs.

Pauls Agriculture Ltd., New Cut West, Ipswich, Suffolk.

Peter Hand (GB) Ltd., Unit 25, Mosside Industrial Estate, Leyland, Lancs. 
Peoples, Dr A. C.

Perry, F. G.

Phillips, G.

Prescott, Prof. J. H. D. Grassland Research Institute, Hurley, Maidenhead, Berks, SL6 5LR.

Reece, M.

Rees, C. P.

Rees, Dr P.

Reeve, Dr A.

Reynolds, Dr I.

Roberts Dr D. J.

Roberts, Dr R. C.

Robinson, T. G.

Rook, Prof. J. A. F.

Round, J.

Scott, Miss S. A.

Simm, Dr G.

Simpkin, P. G.

Slade, C. F. R.

Smith, G. M.

Smith, Miss J.

Smith, R. F. Y.

Speight, B. R.

Speight, D.

Stark, Dr B.

Stranks, M. H.

Strickland, M. J.

Sutton, D. P.

Sutton, Dr J. D.

Tayler, Dr J. C.

Thomas, Dr C.

Greenmount Agricultural College, 22 Greenmount Road, Antrim, BT41 4PU.

BP Nutrition (UK) Ltd., 1 Stepfield, Witham, Essex, CM8 3AB.

W. J. Oldacre Ltd., Cleeve Hall, Bishops Cleeve, Cheltenham, Glos.

Pauls Agriculture Ltd., New Cut West, Ipswich, Suffolk.

Welsh Agricultural College, Llanbadarn Fawr, Aberystwyth, Dyfed.

Dept. of Agriculture, University College of North Wales, Bangor, Gwynedd.

ICI PLC, Agricultural Division, Jealotts Hill Research Station, Nr. Bracknell, Berks, RG12 6 EY.

Seestrasse 38, Ruschlikon 8803, Zurich, Switzerland.

Crichton Royal Farm, West of Scotland Agricultural College, Bankend Road, Dumfries.

MAFF, Great Westminster House, Horseferry Road, London, SW1P 2AE.

Milk Marketing Board, Thames Ditton, Surrey.

Agricultural and Food Research Council, 160 Great Portland Street, London, W1N 6DT.

Nitrovit Ltd., Nitrovit House, Dalton, Thirsk, North York, YO73JE.

MAFF, ADAS, Block A, Coley Park, Reading, Berks.

APAD, East of Scotland College of Agriculture, Bush Estate, Penicuik, Midlothian, EH260QE.

6 Seafield Road, Ainsdale, Southport, Merseyside, PR8 2PF.

Bridgets EHF, Martyr Worthy, Winchester, Hants, SO21 1AP. Scottish MMB, Underwood Road, Paisley, PA3 1TJ.

Dalgety Spillers Feed Ltd., The Promenade, Clifton, Bristol, BS8 3 NJ.

Estate Office, Castlehill, Filleigh, Nr. Barnstaple, N. Devon, EX32 0RG.

Scottish MMB, Underwood Road, Paisley, PA3 1TJ.

Nitrovit Ltd, Nitrovit House, Dalton, Thirsk, North Yorks, YO7 3JE.

MAFF, Block A, Government Buildings, Coley Park, Reading, RG1 6DT.

MAFF, Room 113, Great Westminster House, Horseferry Road, London SW1P 2AE.

Boxworth EHF, Boxworth, Cambridge, CB3 8NN.

Oakes (Millers), Hightown, Congleton, Cheshire.

NIRD, Shinfield, Reading, RG2 9AT.

Agricultural and Food Research Council, 160 Great Portland Street, London, W1N 6DT.

Grassland Research Institute, Hurley, Maidenhead, Berks, SL65LR. 
Thomas, Dr P. C. Thomas, Dr S.

Tippett, G. A. F.

Tow, G. J.

Turner, Miss R. E.

Twigge, J. R.

Unsworth, S.

Wakelam, J. A.

Walsh, Dr J.

Warren, M. E.

Wheelock, Dr V.

Whitehead, J.

Whitehead, J. R.

Whiteoak, R. A.

Whitfield, A.

Wilkinson, Dr J. M.

Wilkinson, Dr R.

Wilson, Prof. P. N.

Yates, A.
Hannah Research Institute, Ayr, KA6 5HL.

North of Scotland College of Agriculture, School of Agriculture, 581 King Street, Aberdeen, AB9 1UD.

ADAS, MAFF, Block 2, Government Buildings, Lawnswood, Leeds, LS16 5PY.

Milk Marketing Board, Thames Ditton, Surrey.

Pauls Agriculture Ltd., Mill Road, Radstock, Nr. Bath, Avon.

BP Nutrition (UK) Ltd., Wincham, Northwich, Cheshire, CW9 6DF.

J. Bibby Agric. Ltd., Adderbury, Banbury, Oxon, OX17 3HL. George A. Palmer Ltd., Oxney Road, Peterborough.

Agricultural Institute of Ireland, Moorepark, Fermoy, Cork.

Milk Marketing Board, Thames Ditton, Surrey.

School of Science and Society, University of Bradford, Bradford. BD7 1DP.

Pauls Agriculture Ltd., Walton Summit, Bamber Bridge, Preston, Lancs.

Cumberland and Westmorland Farmers Ltd., Cumbria House, Gilwilly, Penrith, Cumbria.

I'Anson Bros. Ltd., Thorpe Road, Masham, Nr. Ripon, Yorks. Bayles and Wylie Ltd., Forge Mills, Bestwood, Nottingham.

Chalcombe, Highwoods Drive, Marlow Bottom, Marlow, Bucks, SL7 3PU.

21 Charnwood Fields, Sutton Bonington, Loughborough, Leics. Edinburgh School of Agriculture, West Mains Road, Edinburgh, EH9 3JG.

Farm Business, Northwood House, 93-99 Goswell Road, London, EC1. 


\title{
OPENING REMARKS
}

\author{
J. A. F. ROOK \\ Agricultural and Food Research Council, \\ 160 Great Portland Street, London W1N 6DT
}

$\mathbf{T}$ here is a sense of nostalgia about a meeting on the compositional quality of milk. Chemical composition was of major concern to milk producers, retailers and research workers for two decades or more from the early 1940s. Widespread undernutrition of dairy herds during the winter months of the second world war caused a fall in the solids-not-fat and protein content of milk, in many herds to less than the legal limit. The solids-not-fat content not only recovered but also increased transiently during the early grazing period in association with a fall in milk fat content. This effect became much more evident with the adoption of improved grazing management in the post-war period. After the war, there was also the introduction into the British dairy herd of large numbers of British Friesian cattle, distinguished then by an exceptionally poor chemical composition of their milk, a characteristic shared by many of the native Shorthorn cattle.

Dietary observations concerning milk composition greatly stimulated research. Interest focused on a model diet, extreme in composition, containing 1 to $2 \mathrm{~kg}$ long hay, with an unusually high proportion of flaked maize in the concentrated food, which depressed milk fat content substantially and increased milk protein and, hence, the solids-not-fat content. The diet also induced an extreme, and in some ways atypical, rumen fermentation pattern, characterized by an unusually high proportion of propionic acid in the mixture of ruminal short-chain fatty acids. The simplicity of the relationships that emerged from the comparisons of the model diet with traditional diets tended to conceal, rather than elucidate, what we now know to be an extremely complex relationship between diet and milk composition and, for a time, held back rather than advanced further research.

Nevertheless, research into dietary effects continued, in lower key, stimulated by scientific progress in the understanding of the digestion and metabolism of nutrients and of the physiology of milk secretion, and by practical changes in feeding. These included the introduction of large amounts of fats and oils into dairy foods to increase their energy concentration, the increased use of silage and the recognition of the importance of the detailed composition of milk to its manufacturing properties. From time to time, the effects of non-dietary factors, such as udder disease and milking procedure, received attention but there has been a surprising lack of scientific interest in genetic differences. However, much practical progress has been made in the improvement, through selection and breeding, of the gross composition of the milk of cattle of the Friesian breed.

Extensive information, especially on dietary factors, is now available and explanations have been offered for the metabolic origin of variations in milk composition, although in many instances they are tentative. It is evident that the effects of short-term changes of diet are confounded by lactation stage - through endocrine influences on nutrient partition and mammary physiology - and by long-term effects of nutrition that are, as yet, poorly understood. My impression is that advice can be offered more confidently on the probable causes of observed deficiences of milk composition than on how to produce a desired 
change. The introduction of the new scheme of payment by the Milk Marketing Board, which relates the price of milk to the market value of its main constituents, will inevitably place greater emphasis on a more positive approach to the manipulation of milk composition and it may only be a matter of time before the price structure is altered to take account of more detailed composition. The strengthening evidence for the involvement of saturated fat in the aetiology of heart disease will certainly focus interest on the fatty acid composition of milk fat. I look forward to being brought up to date with current information and to hearing how these new challenges are to be met. 


\section{CONTENTS}

AMIEs, S. J. Changes in the producer payments scheme

HAYES, M. J. Traditional problems of milk quality as experienced by manufacturers of milk products

Tow, G. J. The effect of the compositional quality of milk on new product development

BANKs, W. and MUIR, D. D. Milk utilization and manipulation of composition in the future MulHOLland, J. R. Breeding and milk quality

Crabtree, R. M. Milk compositional ranges and trends ................................ 35

SuTtON, J. D. Feeding and milk fat production ............................................ 43

THOMAs, P. C. Feeding and milk protein production ..................................... 53

THOMAs, C. Milk compositional quality and the rôle of forages ............................ 69

DoDD, F. H. Herd management effects on compositional quality ........................ 77

MoRgAN, H. E. G. Economic implications of compositional quality and production systems

Wilson, P. N. and LAWRenCE, A. B. Research and development implications for the future

\section{POSTER PAPER ABSTRACTS}

Warren, M. E., Amies, S. J. and Robinson, T. G. The effect of changes in the payment scheme on individual farmers

FALLOws, S. J. and WHEELOCK, J. V. Health concerns and milk fat production ...

RoberTs, D. J. and Ferns, H. R. Some effects of cow nutrition on milk composition

FERNS, H. R. and ROBERTs, D. J. The diagnosis of the causes of the production of herd milk with low fat, protein and lactose contents

SLADE, C. F. R. and Wray, J. P. The effect of feeding a complete diet on the milk fat content of milk

ReEs, P. and Rowlinson, P. Fully controlled out-of-parlour feeders and milk

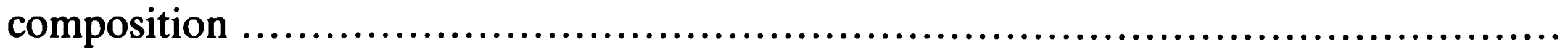

Neilson, D. R., Simm, G. and Parkinson, H. The Langhill Breeding Project: breeding and feeding for total solids production in an experimental dairy herd

Booth, J. M. and Harding, F. Milk composition in herds with high and low mastitis cell counts 